\title{
Legitimacy, Procedural Justice, and Neighborhood Dynamics: Thoughts on Police Reform
}

\author{
Robert Lyle Nicewarner \\ West Virginia University, rlnicewarner@mix.wvu.edu
}

Follow this and additional works at: https://researchrepository.wvu.edu/etd

Part of the Criminology Commons

\section{Recommended Citation}

Nicewarner, Robert Lyle, "Legitimacy, Procedural Justice, and Neighborhood Dynamics: Thoughts on Police Reform" (2019). Graduate Theses, Dissertations, and Problem Reports. 3892.

https://researchrepository.wvu.edu/etd/3892

This Thesis is protected by copyright and/or related rights. It has been brought to you by the The Research Repository @ WVU with permission from the rights-holder(s). You are free to use this Thesis in any way that is permitted by the copyright and related rights legislation that applies to your use. For other uses you must obtain permission from the rights-holder(s) directly, unless additional rights are indicated by a Creative Commons license in the record and/ or on the work itself. This Thesis has been accepted for inclusion in WVU Graduate Theses, Dissertations, and Problem Reports collection by an authorized administrator of The Research Repository @ WVU. For more information, please contact researchrepository@mail.wvu.edu. 
Legitimacy, Procedural Justice, and Neighborhood Dynamics:

Thoughts on Police Reform

Robert L. Nicewarner

Thesis submitted to the Eberly College at West Virginia University

in partial fulfillment of the requirements for the degree of

Masters of Arts in Sociology

James J. Nolan, PhD, Chair

Walter S. DeKeseredy, PhD

Lisa Dilks, $\mathrm{PhD}$

Department of Sociology and Anthropology

Morgantown, WV 2019

Key words/phrases: neighborhood dynamics, procedural justice, police legitimacy, West Virginia Copyright 2019 Robert L. Nicewarner 


\begin{abstract}
Neighborhood Dynamics, Procedural Justice, \& Police Legitimacy: Thoughts on Police Reform Robert L. Nicewarner

Currently, there is much debate about how to alleviate tensions between communities and police. These tensions do not illustrate the full scope of the problem, but show us symptoms of a larger, more structural issue. Many scholars point to procedural justice tactics as a way to increase the legitimacy of the police; thus, creating a safer environment where citizens do not fear the police but respect, obey, and defer to them. However, not every neighborhood is the same and not every neighborhood needs the same kind of policing style. Drawing on theories of collective efficacy and social cognition I propose that to make a community safer there should be evidence of an interdependent relationship between police and the community. To date, an analysis of procedural justice, police legitimacy, and neighborhood dynamics has not been conducted. Using results from an online survey of West Virginia residents aged 18 years or older, I examine how neighborhood dynamics measures can be used to indicate neighborhood atmospheres and how these have impacts on perceptions of fear of crime, risk of crime, reported quality of life, and perceptions of a drug problem. These differing neighborhood types can then inform policy to enact an appropriate policing style, one that leads to interdependence rather than conflict or dependence.
\end{abstract}

Key words/phrases: neighborhood dynamics, procedural justice, police legitimacy, West Virginia 
Table of Contents

INTRODUCTION

$\begin{array}{ll}\text { LITERATURE REVIEW } & 7\end{array}$

Procedural Justice $\quad 7$

POLICE LEGITIMACY $r$

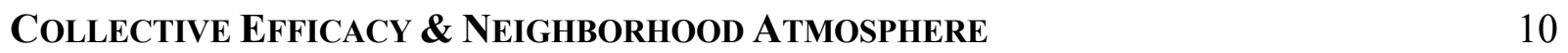

Agency \& efficacy.

RESEARCH OBJECTIVES

$\begin{array}{ll}\text { METHODS } & 16\end{array}$

Participants \& Procedures 16

DEMOGRAPHICS

$\begin{array}{ll}\text { MEASURES } & 17\end{array}$

$\begin{array}{ll}\text { Independent variables. } & 17\end{array}$

Dependent variables. 19

$\begin{array}{lc}\text { RESULTS } & 20\end{array}$

Procedural Justice \& Police Legitimacy 20

NEIGHBORHOOD DYNAMICS $\quad 21$

Procedural Justice, Police Legitimacy, \& Neighborhood Dynamics 22

$\begin{array}{ll}\text { DISCUSSION } & 24\end{array}$

$\begin{array}{ll}\text { LIMITATIONS } & 27\end{array}$

$\begin{array}{ll}\text { PRACTICAL IMPLICATIONS } & 28\end{array}$

$\begin{array}{ll}\text { CONCLUSION } & 30\end{array}$

REFERENCES

FIGURE 1: NEIGHBORHOOD DEVELOPMENTAL STAGES 35

TABLE 1 - PHONE SURVEY VS. ONLINE SURVEY PROPORTION COMPARISONS

TABLE 2 - DV: DRUG PROBLEM

TABLE 3 - DV: FEAR OF CRIME

TABLE 4 - DV: OVERALL QUALITY OF LIFE

TABLE 5 - DV: RISK OF CRIME

APPENDIX: QUALITY OF COMMUNITY LIFE IN WEST VIRGINIA 39 


\section{Introduction}

Policing is a fundamental part of American society and has been the recipient of much attention from scholars and media outlets in the past few years. According to The Washington Post's national database on police use of fatal force 998 people were killed by police in 2018 . A description of their methods details, "The post is documenting only those shootings in which a police officer, in the line of duty, shoots and kills a civilian ... The post is not tracking deaths of people in police custody, fatal shootings by off-duty officers or non-shooting deaths" (Tate et al., 2018). Another database, Mapping Police Violence, reports that police killed 1,166 people in 2018. This site also states that African Americans are three times more likely to be killed by police than whites. Additionally, this site reports that $99 \%$ of cases in 2015 have not resulted in any officers involved being convicted of a crime. This database defines "police killing” as: “A case where a person dies as a result of being chased, beaten, arrested, restrained, shot, pepper sprayed, tasered, or otherwise harmed by police officers, whether on-duty or off-duty, intentional or accidental” (MappingPoliceViolence.org, 2018).

Independent researchers began compiling this data in response to the poor data-collection methods of government databases (Williams, Bowman, \& Jung, 2016). This inadequacy was brought to the forefront after high profile cases of police abuse of force and police killings in America started gaining more public attention through the media. Fatal cases such as those of Alton Sterling in Baton Rouge, LA (2016); Freddie Gray in Baltimore, MD (2015); Walter Scott in Charleston, SC (2015); Tamir Rice in Cleveland, OH (2014); Eric Garner in New York, NY (2014); and Michael Brown in Ferguson, MO (2014). The oldest of these cases, that of Michael 
Brown, prompted civilian protest and action all across the country, most notably, the emergence of the Black Lives Matter ${ }^{1}$ movement.

With so much public attention on police misconduct in general, the federal government was urged to investigate the departments where some of the above cases took place. D'Souza, Weitzer, and Brunson (2018) compared the findings from the Department of Justice's (DOJ) investigations in Baltimore, Chicago, Ferguson, and New Orleans. The study revealed three consistent problems across the four DOJ reports: improper stops, searches, and arrests; use of language/ verbal abuse; and use of excessive or unnecessary force. First, the authors found that reports for Baltimore, Ferguson, and New Orleans included issues relating to patterns of improper stops, searches, and arrests (D’Souza, Weitzer, \& Brunson, 2018, p. 5). This analysis revealed that these constitutional violations resulted from "questionable policies" and "deficient training and oversight". The article discusses issues relating to zero-tolerance policies that focused on statistics and the resulting top-down incentives for officers to conduct business in this way. Ferguson stood out in the author's analysis because of the department's revenue generating policies - a "policing-for-profit policy" (D’Souza, Weitzer, \& Brunson, 2018, p. 6). The authors note that this practice not only decreased trust and support for police, it created a culture of competition where officers competed against each other to get the most tickets or citations. This article also notes, “African American’s were disproportionately impacted by stops, searches, and arrests" (D’Souza, Weitzer, \& Brunson, 2018, p. 8). The authors found these violations to be both prevalent and discriminatory, having implications for perceptions of police in these communities.

\footnotetext{
${ }^{1}$ The "Black Lives Matter" movement has become a "Global Network" with a mission to "build local power and to
} intervene in violence inflicted on Black communities by the state and vigilantes" (BlackLivesMatter.com, 2018). 
Second, this analysis found "Racist language was the most commonly described type of verbal misconduct in DOJ's reports" (D'Souza, Weitzer, \& Brunson, 2018, p. 9). Specifically, in Chicago and Ferguson, "reports also noted officers' sharing of racially derogatory opinions and humor through work emails and social media" (Ibid). Additionally, the DOJ found that in Chicago, 980 citizen complaints were recorded, but only $1.3 \%$ of them were sustained. Not only were these departments not being respectful of citizens, they were also not taking complaints seriously. These reports revealed racism in verbal exchanges and communications of officers, but also revealed the sexist attitudes held by these officers. Evidence of sexist language being used was found in all departments with the exception of Ferguson (D'Souza, Weitzer, \& Brunson, 2018, p. 10). The sexist leanings of officers had its greatest impact on investigations of violence against women resulting in a "culture [that] tolerates and encourages under-enforcement and under-investigation of violence against women" (Ibid).

Lastly, the DOJ reports found that improper use of force was a major problem, "presented as a deeply embedded practice, not attributable to bad apples or isolated episodes" (D'Souza, Weitzer, \& Brunson, 2018, p. 12). Underreporting, lack of de-escalation training, overuse of weapons, officer retaliation, and problematic foot and vehicle chases all contributed to the issue of improper use of force. The authors also acknowledge, "individuals in police custody who were being transported to a police station were especially vulnerable" (D’Souza, Weitzer, \& Brunson, 2018, p. 15). In addition to those in police custody, "blacks and the mentally ill" were disproportionately vulnerable to improper use of force (D’Souza, Weitzer, \& Brunson, 2018, p. 16). Each of these issues directly impact how safe individuals feel in their community. This comparison of DOJ findings from four distinct cities reveals structural issues within the way 
police function and performs their duties. These structural issues break down trust and social cohesion between the public and the police. What then can be done to remedy this situation?

One popular answer to this question is for police departments to adopt a procedural justice approach when dealing with the public. In fact, in 2015, former President Obama initiated a task force to examine the issue more closely - The President's Task Force on $21^{\text {st }}$ Century Policing. This task force was comprised of researchers, academics, practitioners, and law enforcement personnel. The findings from this task force support the claim that procedural justice tactics are of the utmost importance in improving police-community relations. More specifically, the task force claims that increasing procedural justice will increase police legitimacy.

A procedural justice view incorporates four interactional concepts - participation, neutrality, dignity/respect, and trust. These concepts focus on the relationship between citizens and authority figures. Citizens think more highly of that figure if they feel they have participated in the interaction, the officer acted neutral, the officer treated them with dignity and respect, and they trust that the officer acted in their best interest (Tyler, 1998). Tyler's work emphasizes the notion that how officers interact with citizens can shape the way citizens see the police. Specifically, Tyler and his colleagues found that procedural justice can increase police legitimacy. According to Tyler (2006), legitimacy results in increased compliance, cooperation, and deference, factors that increase the likelihood of individuals obeying the law.

The procedural justice perspective relies on the transactional nature of interactions between community and the police. For example, if the police give respect to the citizens, the citizens will in turn give the police respect, resulting in increases of police legitimacy that lead to 
compliance, cooperation, and deference. This paper explores how increases in legitimacy and procedural justice influence perceptions of safety and quality of life in communities.

This theory of interaction then begs the question, what about context? How might perceptions of procedural justice and police legitimacy be influenced by the context in which they occur? Consider the previous discussion on the DOJ findings from Baltimore, Chicago, Ferguson, and New Orleans. These cities all displayed structural antecedents that directly contradicted the basic tenants of procedural justice. Are we to assume that adopting procedural justice practices would negate a history of police misconduct? Indeed, procedural justice practices alter the way officers interact with citizens, but are these interactional reforms enough to improve lives of individuals? This paper furthers procedural justice and police legitimacy research by exploring the role of context. That is, do procedural justice and police legitimacy still impact the daily lives of individuals when specific aspects of context are considered?

Aside from looking at the crisis in policing from the perspective of what the police alone can do to; we can examine the problem through a new, understudied perspective - neighborhood dynamics. Neighborhood dynamics is a contextual variable that refers to the psychodynamic processes in neighborhoods and communities that are latent, the result of social structure, and can be the source of structural change (Nolan, Hinkle, \& DeKeseredy, 2018). Using this contextual perspective, the question changes from "what can the police do to ensure citizens follow the law" to "how can the police work with citizens to improve conditions in the community". This is key to reform as the change that we need to see is in the structure of policing. There are a number of ways in which individuals can change a structure: with others (collective agency); with the help of an expert serving as a proxy (proxy agency); or by the 
individual acting alone (personal agency) (Bandura, 2001). This paper focuses on the first two mediums for change, collective agency and proxy agency.

Nolan, Conti, and McDevitt (2004) use neighborhood collective efficacy measures to identify different neighborhood atmospheres. These different atmospheres are interdependence, dependence, and conflict/frustration. These measures capture context because they include perceptions of collective efficacy as well as perceptions of proxy efficacy. That is, they get at how people view their neighbors or community members as well as how people view informal and formal crime control mechanisms.

An assessment of neighborhood dynamics ${ }^{2}$ is necessary and useful in improving safety and quality of life in communities. Using self-report data on neighborhood dynamics and perceptions of the police, this paper seeks to better understand risk of crime, fear of crime, quality of life, and perceptions of drug problems in communities. The utility of using this approach is that it considers neighborhood and community variation within places. This analysis utilizes data collected as part of the "Quality of Community Life Survey" that was administered online to West Virginia residents aged 18 years or older. The following research questions are addressed:

R1: How are procedural justice and police legitimacy related to fear of crime, risk of crime, perceptions of drug problems, and quality of community life?

R2: How are neighborhood dynamics related to fear of crime, risk of crime, perceptions of drug problems, and quality of community life?

\footnotetext{
2 Borrowing from Nolan, Hinkle, and DeKeseredy (2018), in this paper neighborhood dynamics refer to the shared emotions created when residents and police meet or fail to meet expectations related to community safety. The exact boundaries of neighborhood are not established in this study but rely on how respondents subjectively define the space they call "neighborhood" and the people who live there.
} 
R3: How influential are perceptions of procedural justice and police legitimacy in regard to fear of crime, risk of crime, perceptions of drug issues, and quality of community life when accounting for neighborhood dynamics?

R4: What are the implications for police reform?

\section{Literature Review}

\section{Procedural Justice}

Historically, the term procedural justice has been defined as "optimal distribution of control" (Thibuat \& Walker, 1975, p. 2), but it has since been applied more specifically to the police. Tom Tyler (2004) identifies the following key features of procedural justice in policing. First is participation. People are more satisfied when they feel that they have an influence on the situation (Tyler, 2004, p. 94). Second is neutrality, citizens hold more favorable views of the police when they feel that the officer is not being biased towards them, they want to see evidence of a level playing field (Ibid). Third, people value being treated with dignity and respect by legal authorities (Ibid). The final feature of procedural justice is trust in the decision maker or in this case, the police, "people feel that procedures are fairer when they trust the motives of the decision maker" (Tyler, 2004, p. 95).

Past research supports these findings. Tyler's (1998) study found that seven aspects of procedural justice make an independent contribution to assessments of public satisfaction with police: the effort of the authorities to be fair; their honesty; whether their behavior is consistent with ethical standards; whether opportunities for representation are given; the quality of the decisions made; whether opportunities to appeal exist; and whether the behavior of the authorities shows bias (p. 121). Tyler (2006), again, studied Chicagoans perceptions of satisfaction with police, finding that procedural justice was most influential in citizens 
developing these perceptions of police. Tyler and Huo (2002), yet again, found that how police treated people accounted for more variance in public evaluations of police than variations in the quality of police performance: "The authors argued that when police change the way they interact with people, moving from a command-and-control orientation to a fair and respectful disposition, evaluations become more favorable (Hinds \& Murphy, 2007, p. 29).

Tyler and Sunshine (2003) found that 5 variables accounted for $47 \%$ of the variation in public satisfaction with police: legitimacy, procedural justice, distributive justice, police performance, and income level. Similarly, Hinds and Murphy (2007) replicated Tyler's study on procedural justice in Australia. They found that police performance was almost equally as important as procedural justice (Hinds \& Murphy, 2007). We see that work has been done to establish procedural justice leads to increases in public satisfaction of police. Tyler (2006) has extended this research by asserting that procedural justice increases the legitimacy of the police.

\section{Police Legitimacy}

According to Tyler (2004), police legitimacy can be understood as "the belief that the police are entitled to call upon the public to follow the law and help combat crime and that members of the public have an obligation to engage in cooperative behaviors. When people feel that an authority is legitimate, they authorize that authority to determine what their behavior will be within a given set of situations" (pp. 86-87). Furthermore, Tyler (2004) claims that when an authority, such as the police, is seen as legitimate, individuals "are more willing to cooperate with legal authorities" including "both deferring to their decisions during personal encounters and generally obeying legal rules in their everyday lives", and "are more cooperative in helping the police to deal with crime in their communities" (p. 89). 
Police legitimacy relates to procedural justice because "the legitimacy of authorities and institutions is rooted in public views about the appropriateness of the manner in which the police exercise their authority" (Tyler, 2004, p. 91). If the police act procedurally just, citizens are more likely to see them as legitimate authorities. However, as the DOJ reports previously discussed reveal, police have not been acting procedurally just and this has resulted in a legitimacy crisis. Furthermore, "these procedural judgments are distinct from judgments about the effectiveness, valence, or fairness of the encounters of those activities" (Ibid). In short, Tyler is arguing for the adoption of procedural justice practices so the police can be seen as more legitimate, resulting in higher rates of public cooperation, compliance, and deference. The assumption that follows from these claims is that procedural justice would ultimately lead to safer communities. This paper examines how procedural justice and police legitimacy influence perceptions of drug problems, fear of crime, quality of life, and risk of crime.

Tyler and colleagues' years of research on procedural justice and police legitimacy were so well received that in 2015 former President Obama commissioned a task force dedicated to "strengthen[ing] community policing and trust among law enforcement officers and the communities they serve" (p. III). In fact, the first "pillar" for success is titled "Building Trust \& Legitimacy". This report urged law enforcement agencies around the country to adopt a procedural justice approach in hopes of increasing their legitimacy. While summarizing the past research on police legitimacy and procedural justice, this report also serves as a road map for departments across the country with roughly 9 recommendations for law enforcement. This paper furthers research on procedural justice and police legitimacy by using data from West Virginia residents to determine their independent effects on fear of crime, risk of crime, perceived drug problems, and quality of community life. Additionally, this paper examines the 
influence of procedural justice and police legitimacy while accounting for neighborhood dynamics.

\section{Collective Efficacy \& Neighborhood Atmosphere}

As a starting point for reexamining neighborhood level characteristics as they pertain to outcomes of social disorder and quality of life, this paper uses ideas from Sampson and Raudenbush (1999). Sampson and Raudenbush (1999) offer "A theory combining structural constraints with local collective efficacy" (p. 605). This theory sees social control "as the capacity of a social unit to regulate itself according to desired principles - to realize collective, as opposed to forced, goals" (p. 610). Specific attention is given to the "informal mechanisms by which residents initiate or achieve social control" (Ibid). The authors make note that informal control does not have to include "direct confrontation or exclude police or other formal channels of recourse" (Ibid). For example, informal control might be seen in neighbors calling the president of their Home Owner's Association, who in turn might call the police. Sampson and Raudenbush (1999) claim that their theory "recognizes the articulation among the private (family), parochial (neighborhood), and formal (police) orders but stresses the agency of residents in establishing these connections" (Ibid) - something that procedural justice and police legitimacy research excludes. Sampson and Raudenbush (1999) propose "A theory of collective efficacy that does not render structural constraints irrelevant; rather, it proposes mediating mechanisms while at the same time insisting on an independent role for agency in all corners of social structure" (p. 613). Again, improving safety and quality of life is not solely the responsibility of the police. Procedural justice research relies on altering how police behave to improve community life, while a theory of collective efficacy involves not only the police, but also includes neighborhood agency and efficacy beliefs as well. 


\section{Agency \& efficacy.}

The procedural justice approach attempts to answer the question of how police can change citizen perceptions by using interaction as the medium for change. The change offered by neighborhood dynamics is more collaborative and situationally based. As Nolan, Hinkle, and DeKeseredy (2018) argue, "the dynamic process begins with the expectations the police and community have of each other. Either [residents] believe the police are primarily responsible for crime control in the neighborhood (proxy agency) or that they (residents) are co-responsible for creating safe conditions in the community (collective agency)" (p. 13). Bandura (2001) asserts that there are three modes of human agency: personal, proxy, and collective. Personal agency relates to ways in which individuals can enact change in their lives. Proxy agency relates to ways in which individuals elicit help from an outside entity to enact that change. Collective agency refers to ways in which groups or collectives work to enact change.

The term collective efficacy is "a construct used to describe and assess neighborhoodlevel social control" (Nolan, Conti, \& McDevitt, 2004, p. 100) that involves "cohesion among residents combined with shared expectations for the social control of public space" (Sampson, Raudenbush, \& Earls, 1997, p. 603). Sampson, Raudenbush, and Earls (1997) identified structural constraints in neighborhoods as "concentrated disadvantage, residential (in)stability, population density, and mixed-land use (private and commercial)" (as cited by Nolan, Conti, \& McDevitt, 2004, p. 100).

Nolan, Conti and McDevitt (2004) argue that collective efficacy is present everywhere but can come in different "flavors". Donnermeyer and DeKeseredy (2014) assert that there are "forms of collective efficacy or social organization that allow individuals to learn about and behave in ways that sustain and reinforce their offending" (p. 9). Their research highlights the 
fact shared community goals are not always positive. For example, as their research discovered, some rural police forces exhibit a common goal of not pursuing domestic violence charges, particularly when one of their own is suspected. Similar mechanisms are at play when police misconduct is brought up - police officers shared goal of protecting their own interferes with the good of the community.

Nolan and colleagues have identified 3 distinct neighborhood atmospheres ${ }^{3}$ based on citizen perceptions of their community members and met or failed expectations of the police: dependent neighborhoods, conflict neighborhoods, and interdependent neighborhoods. A dependent neighborhood is one where "community members want the police to solve problems related to public order and the police are willing, and sometimes able, to do so" (Nolan, Conti, \& McDevit, 2004, p. 107). However, the problem arises when these expectations are not met or when they are not even understood or articulated. The second neighborhood atmosphere is labeled "conflict/dissatisfaction" and is seen when "Residents still see the police as having the primary responsibility for maintaining order in the neighborhood and keeping the residents safe, but they believe the police are just not doing a very good job" (Ibid). This is the kind of neighborhood where you see high numbers of complaints against the police, individuals unwilling to cooperate with the police, and where tensions are high between community and police. The last neighborhood atmosphere is titled "interdependence" and is evidenced by high levels of collective efficacy with both formal and informal agents of social control. Specifically, interdependent communities exhume a strong, trusting community network where community

\footnotetext{
3 These neighborhood atmospheres are not static but very much dynamic. Additionally, one neighborhood or community can have evidence of all three types. These concepts are best used to show which type is more present than the others.
} 
members work with police as needed but only when the community itself cannot address the issue.

Past research examined the importance of these differing neighborhoods. Nolan et al. (2018) examined these relationships in Wilmington, Delaware; Cleveland, Ohio; and West Virginia. The Neighborhood Atmosphere Survey (NA) was conducted in Wilmington and Cleveland during 2008 and 2009 in 7 neighborhoods (5 in Cleveland and 2 in Wilmington) resulting in 544 completed surveys. Additionally, Nolan et al. (2018) used data from the West Virginia Community Quality of Life Survey (WVCQLS), which was a telephone survey of a random sample of West Virginia residents during the summer and fall months of 2016. In these three locations, Nolan found empirical support for the neighborhood atmospheres discussed above and found that victimization and fear of crime were highest in conflict areas and lowest in interdependent areas.

Findings from Nolan et al.'s (2018) analysis support the ideas put forth in this paper. First, the authors found that interdependence is negatively related to community crime and disorder, fear of crime, and burglary and theft victimization in both Cleveland and Wilmington. Additionally, "As conflict scores increase by one standard deviation, the odds increase significantly for the occurrence of community crime and disorder $(+79 \%)$, fear of crime $(+64 \%)$, and burglary or theft victimization (+54\%)" (p. 18). Second, Nolan et al. (2018) found that, in West Virginia, "Interdependent communities are by far the safest, with a $1 \%$ chance of reporting a burglary or theft in the past 12 months, a $10 \%$ chance of experiencing some form of community disorder, and a 7\% chance of reporting being fearful of a crime" (p. 19).

\section{Research Objectives}


Procedural justice and police legitimacy have been examined in a number of settings while controlling for a number of individual-level variables. Similarly, neighborhood dynamics have been examined in a number of environments while excluding perceptions of procedural justice and police legitimacy. This paper offers a unique perspective as it accounts for neighborhood atmosphere as well as perceptions of procedural justice and police legitimacy. Research on procedural justice claims that this is a police reform strategy that can improve community-police relations by increasing perceptions of police legitimacy. However, research on collective efficacy reveals that perceptions are created at the local level and are strongly influenced by local context. Neighborhood dynamics offer a new way of understanding neighborhood context rather than assuming that more procedural justice will improve conditions in all neighborhoods.

Also, the tenants of procedural justice policing should already be implemented anyway, regardless of community-police relations. Claiming that giving citizens procedural justice would fix deep-rooted, structural issues in policing specifically, and the criminal justice system in general, is simply misguided. Treating citizens with respect and dignity, giving them a voice, being transparent, and being unbiased are things that should already be commonplace within policing, not some new reform strategy.

By collecting data on neighborhood dynamics, researchers put the power in the hands of the community - asking them how they currently deal with issues, how they interact with their neighbors, and asking them what they expect from police. This study starts with the assumption that police are part of the community they serve and that they do influence risk of crime, fear of crime, perceived drug issues, and overall quality of life while also highlighting the importance of the rest of the community. As research on collective efficacy argues, combating these issues 
takes the whole community. Procedural justice and police legitimacy research place the responsibility solely in the hands of the police.

Scholars have examined procedural justice in light of increasing police legitimacy. The assumption is that increased police legitimacy will decrease crime and social disorder because people will be more willing to cooperate, comply, and defer to police. This perspective leaves out the notion that context matters. Relying on how police alone can alter perceptions of safety in a neighborhood excludes the varying degrees of collective agency each neighborhood holds in dealing with problems. As Vitale (2018) puts it, "By conceptualizing the problem of policing as one of inadequate training and professionalization, reformers fail to address how the very nature of policing and the legal system served to maintain and exacerbate... inequality" (p. 14). In other words, Vitale is arguing that the problem with policing is not how they are policing, but in the function or structure of policing.

Vitale is not the only scholar who has issues with procedural justice. Worden and Mclean (2017) published an entire book critiquing this perspective. They found that implementing procedural justice was more difficult than simply treating others with respect, it was more of an organizational issue. They also found contradicting evidence in terms of procedural justice improving satisfaction with police. That is, in some places, procedural justice just wasn't enough to mend these broken relationships between police and community. Additionally, it is hard to get officer buy in, regardless of who the directive for reform comes from. Worden and Mclean (2017) found that when police use their authority is more influential rather than how (p. 12).

This study has three main research objectives. First, to examine the influence of procedural justice and police legitimacy on risk of crime, fear of crime, perceived drug issues, and quality of life. Second, to examine the influence of neighborhood dynamics measures on risk 
of crime, fear of crime, perceived drug issues, and quality of life. Lastly, to examine the influence of procedural justice, police legitimacy, and neighborhood dynamics on risk of crime, fear of crime, perceived drug issues, and quality of life. Ultimately, this paper is interested in examining if the role of procedural justice and police legitimacy is as significant when controlling for neighborhood atmosphere.

\section{Methods}

\section{Participants \& Procedures}

In the summer of 2017, an online questionnaire was distributed on Facebook via a snowball sampling method. An ad was posted on the Research Team's Facebook pages and the Research Center on Violence's Facebook page. Friends were urged to complete the survey if they were current residents of West Virginia and 18 years old or older and to share the post when finished with the survey. This method of sampling is relatively new, but some researchers have used it to study subpopulations or hard to reach populations in a swift and cost effective and way. (See Bhutta, 2012 for a review).

This survey yielded a total of 1,431 completed surveys. Participants were individuals who indicated that they were 18 years or older and currently a West Virginia resident. The survey was administered using the survey platform Qualtrics. Distributing the survey over the Internet was part of an attempt by researchers to compare the findings from this non-probability sample with a probability sample obtained as part of the West Virginia Quality of Community Life survey administered via probability sample over the phone.

Table 1 shows how some of the variables compare between the phone survey and the online survey. A comparison of variable proportions revealed that the data gathered online fits within the $95 \%$ confidence intervals of some of the variables measured in the traditional phone 
survey. The online survey obtained a little over three times the number of responses for the phone survey in a matter of weeks rather than in a span of a year. Despite the high number of responses, this survey has limitations resulting from this method of data collection that will be discussed later.

The survey was a collaborative effort with contributions from Dr. James Nolan, Dr.

Walter DeKeseredy, and myself. There are five substantive sections of the survey: fear of crime, risk of crime, perception of drugs, community dynamics, and policing dynamics.

\section{Demographics}

Due to the nature of this non-probability sample the findings relating to this study are not generalizable and do not represent the views of the state as a whole. Some key demographics of this unique non-probability sample are as follows. About $95 \%$ of the respondents in this sample were white or Caucasian. Most of the respondents are female (76\%) and heterosexual (90\%). Most (59\%) of the respondents in the sample reported that their annual income, before taxes, was more than the medium household income of West Virginia in $2016(\sim \$ 42,000)$. This survey contains survey responses from at least one person from each of the fifty-five counties in West Virginia with the exception of Logan, McDowell, and Mingo counties. For comparison, in 2016, the United States Census Bureau reported that West Virginia was 93. 6\% white and 50.4\% female.

\section{Measures}

\section{Independent variables.}

Procedural justice is measured by asking respondents to indicate their level of agreement with three questions taken directly from a study conducted by Hinds and Murphy (2007). Respondents were asked to report their level of agreement with the following statements: 
"Would you say that... (1) the police are concerned about respecting a citizen's individual rights; (2) the police treat people as if they can be trusted to do the right thing; (3) the police treat people as if they only do the right thing when forced to." Agreement was measured using the following five-point Likert scale: (1) strongly disagree, disagree, neutral, agree, strongly agree (5). For analytical purposes these three questions sre combined to create a "procedural justice" score ranging from 3 (low procedural justice) to 15 (high procedural justice). This composite variable received an Alpha score of 0.78 .

Police legitimacy is measured by asking respondents to indicate their level of agreement, using the same 5-point Likert scale as above, with 2 questions taken directly from Sunshine and Tyler (2003). Respondents were asked to report their level of agreement with the following statements: "Would you say that... (1) you should accept the decisions made by the police, even if you think they are wrong; (2) communities work best when people follow the directives of the police". These questions aimed at understanding people's perceived obligation to obey, a result of the police being legitimate. For analytical purposes, responses from these two questions are combined to create a "police legitimacy" score, ranging from 2 (low police legitimacy) to 10 (high police legitimacy). This composite variable received an Alpha score of 0.68 .

To understand varying levels of collective and proxy efficacy beliefs, Nolan, Conti, and McDevitt (2004) and Nolan et al. (2018) created measures that are included in the survey. These 18 questions asked respondents to report their level of agreement with the following statements: "Generally speaking, the people in my neighborhood or community... (1) know how to work together to prevent crime (2) don't get along with one another; (3) know how to deal with minor community problems; (4) are willing to help one another; (5) watch out for each other's property; (6) tell each other what is going on; (7) do not work well together on community 
problems; (8) trust each other; (9) rely heavily on each other; (10) are frustrated with the police; (11) call the police for most community problems; (12) think the police don't seem to care; (13) think the police do very little to prevent crime; (14) trust the police to be highly effective crime fighters; (15) assume the police know what is going on; (16) rely heavily on the police to deal with all kinds of neighborhood problems; (17) think the local police are ineffective; (18) have confidence that the police alone are capable of preventing crime." All questions were measured with the same five-point Likert scale used to measure procedural justice and police legitimacy.

For analytical purposes, a factor analysis of these 18 questions was conducted, using a Varimax rotation. This analysis resulted in questions loading on 3 factors that reveal the neighborhood atmospheres: interdependence ${ }^{4}$, conflict $^{5}$, and dependence ${ }^{6}$.

\section{Dependent variables.}

Respondents were asked questions relating to their perceptions of drug problems in their community, fear of crime, overall quality of life, and risk of crime. To capture perceptions of drug problems, respondents were asked if they thought drug use or drug dealing was a big problem, a small problem, or not a problem at all. This variable is dichotomized as "not a problem/small problem" $=0$ and "a big problem" $=1$.

Fear of crime is captured by asking respondents to report their level of concern about the following things happening to them in their community: having your home broken into; vandalism to your home or car; being mugged/robbed; being physically attacked because of your skin color, ethnic origin, or religion; being sexually assaulted by strangers; being physically attacked by strangers; being physically attacked by someone you know; and being sexually

\footnotetext{
${ }^{4}$ Questions 1, 3, 4, 5, 6, 8, and 9

${ }^{5}$ Questions 2, 7, 10,12,13, and 17

${ }^{6}$ Questions 11, 15, 16, and 18
} 
assaulted by someone you know. The answer choices were: not at all worried; not very worried; fairly worried; and very worried. Individually, these were first dichotomized as "not at all worried" or "not very worried" = 0 and "fairly worried" or "very worried" $=1$. These dichotomous variables are then used to create an "overall fear" item where $0=$ "not worried about any of the 8 items" and $1=$ "worried about at least 1 of the items".

To measure overall quality of life respondents were directly asked, "How would you rate the overall quality of life in West Virginia?" The following answer choices were provided: very good, good, neither bad nor good, bad, very bad. This is dichotomized to reflect a score of 0 if it was bad, very bad, or neither good nor bad, and a score of 1 if it was very good or good.

Risk of crime is measured by respondents reporting if they had experienced any of the following crimes in the previous twelve months: a break-in, outside theft, robbery, physical assault, motor vehicle theft, assault with a weapon, or verbal or physical hate crime. A risk of crime variable was created to reflect a score of 0 if they had not experienced any of the crimes and a score of 1 if they had experienced at least one of them.

A complete list of all survey measures can be found in the Appendix.

\section{Results}

\section{Procedural Justice \& Police Legitimacy}

Binomial logistic regression is used to examine procedural justice and police legitimacy's influence on the dependent variables, excluding neighborhood atmosphere variables, and these are found in model 1 of Tables 2-5. Procedural justice and police legitimacy, together, have influence on two of the dependent variables, overall quality of life and risk of crime. As police legitimacy increases, overall quality of life increases by $24 \%(\mathrm{p}<.01)$, controlling for procedural justice. As individuals perceive more procedural justice, overall quality of life increases by $34 \%$ 
$(\mathrm{p}<.01)$, controlling for police legitimacy (Table 4, Model 1). Procedural justice and police legitimacy are associated with decreases in risk of crime. As police legitimacy increases, risk of crime decreases by $12 \%(\mathrm{p}<.05)$, controlling for procedural justice. Similarly, as procedural justice increases, risk of crime decreases by $12 \%(\mathrm{p}<.01)$, controlling for police legitimacy (Table 5, Model 1). Procedural justice and police legitimacy, together, are not statistically significant in relation to perceptions of drug problems or fear of crime. Interestingly, procedural justice is related to decreases in fear of crime. As perceptions of procedural justice increase, fear of crime decreases by $12 \%(\mathrm{p}<.01)$ (Table 3 , Model 1$)$.

\section{Neighborhood Dynamics}

Binomial logistic regression is also used to examine the relationship between neighborhood atmosphere types and the dependent variables, excluding police legitimacy and procedural justice.

First, as interdependence increases by one standard deviation ${ }^{7}$, participants are $31 \%$ less likely to perceive drugs as a problem in the community $(\mathrm{p}<.01)$, controlling for dependence and conflict. As conflict increases by one standard deviation, participants are $92 \%$ more likely to perceive drugs as a problem in the community $(\mathrm{p}<.01)$, controlling for interdependence and dependence. As dependence increases by one standard deviation, participants are $38 \%$ more likely to perceive drugs as a problem in the community $(\mathrm{p}<.01)$, controlling for interdependence and conflict (Table 2, Model 2).

Second, as interdependence increases by one standard deviation, participants are $44 \%$ less likely to be fearful of crime in the community $(\mathrm{p}<.01)$, controlling for dependence and conflict. As conflict increases by one standard deviation, participants are $74 \%$ more likely to be

\footnotetext{
7 The pasted factor scores are z scores, with 0 as mean and $1=$ one standard deviation and $1.96=2$ standard deviations.
} 
fearful on crime in the community $(\mathrm{p}<.01)$, controlling for interdependence and dependence.

Dependence was not statistically significant in relation to fear of crime in the community (Table 3, Model 2).

Third, as interdependence increases by one standard deviation, participant's overall quality of life are 2.97 times greater $(\mathrm{p}<.01)$, controlling for conflict and dependence. As conflict increases by one standard deviation, a participant's overall quality of life decreases by $56 \%$ $(\mathrm{p}<.01)$, controlling for interdependence and dependence. Dependence was not statistically significant in relation to overall quality of life (Table 4, Model 2).

Fourth, as interdependence increases by one standard deviation, risk of crime decreases by $33 \%$ ( $p<.01)$, controlling for conflict and dependence. As conflict increases by one standard deviation, risk of crime increases by $54 \%(\mathrm{p}<.01)$, controlling for interdependence and dependence. As dependence increases by on standard deviation, risk of crime decreases by $18 \%$ $(\mathrm{p}<.01)$, controlling for interdependence and conflict (Table 5, Model 2).

\section{Procedural Justice, Police Legitimacy, \& Neighborhood Dynamics}

The final models include analyses of the influence of police legitimacy, procedural justice, and the neighborhood atmosphere variables on the dependent variables.

First, as interdependence increases by one standard deviation, participants are $29 \%$ less likely to perceive drugs as a problem in their community $(\mathrm{p}<.01)$, controlling for conflict, dependence, procedural justice, and police legitimacy. Conversely, as conflict increases by one standard deviation, participants are 1.89 times more likely to perceive drugs as a problem in their community $(\mathrm{p}<.01)$, controlling for interdependence, dependence, procedural justice and police legitimacy. As dependence increases by one standard deviation, participants are $42 \%$ more likely to perceive drugs as a problem in their community $(\mathrm{p}<.01)$, controlling for interdependence, 
conflict, procedural justice, and police legitimacy (Table 2, Model 3). Procedural justice and legitimacy are not statistically significant in relation to perceptions of a drug problem in the community, indicating that in relation to perception of drug issues (Table 2) Model 1 suffers from omitted variable bias.

Second, as interdependence increases by one standard deviation, participants are $44 \%$ less likely to be fearful of crime in the community $(\mathrm{p}<.01)$, controlling for conflict, dependence, procedural justice, and police legitimacy. As conflict increases by one standard deviation, participants are $76 \%$ more likely to be fearful of crime in the community $(\mathrm{p}<.01)$, controlling for interdependence, dependence, procedural justice, and police legitimacy. Procedural justice, legitimacy, and dependence are not statistically significant in relation to fear of crime in the community (Table 3, Model 3).

Third, as interdependence increases by one standard deviation, overall quality of life is 3.08 times higher $(\mathrm{p}<.01)$, controlling for conflict, dependence, procedural justice, and police legitimacy. As conflict increases by one standard deviation overall quality of life decreases by $53 \%(\mathrm{p}<.01)$, controlling for interdependence, dependence, procedural justice, and police legitimacy. As legitimacy increases, overall quality of life increases by $19 \%(p<.05)$, controlling for procedural justice, interdependence, conflict, and dependence. Procedural justice and dependence are not statistically significant in relation to overall quality of life (Table 4, Model $3)$.

Lastly, as interdependence increases by one standard deviation, risk of crime decreases by $30 \%(\mathrm{p}>.01)$, controlling for conflict, dependence, procedural justice, and police legitimacy. As conflict increases by one standard deviation, risk of crime increases by $51 \%(\mathrm{p}<.01)$, controlling for interdependence, dependence, procedural justice, and police legitimacy. Again, in 
this model, we see that procedural justice, police legitimacy, and dependence are not statistically significant in relation to risk of crime in the community (Table 5, Model 3).

\section{Discussion}

The first purpose of this study was to test the relationship between procedural justice and police legitimacy and perceptions of drug problems; fear of crime; overall quality of life; and risk of crime. Measures for procedural justice and police legitimacy are taken directly from leading scholars in the field. The purpose here is to test their hypotheses in the setting of West Virginia. Procedural justice and police legitimacy are statistically significant in the models concerning overall quality of life (Table 4, Model 1) and risk of crime (Table 5, Model 1). The data suggest that individuals who see the police as more legitimate and who perceive more procedural justice report higher quality of life than those who see the police as less legitimate and who perceive less procedural justice. Additionally, individuals who see the police as more legitimate and perceive more procedural justice have a lower risk of criminal victimization than those who do not see the police as legitimate and those who perceive less procedural justice. Interestingly, procedural justice is related to decreases in fear of crime (Table 3, Model 1), but legitimacy was not statistically significant. More procedural justice and police legitimacy result in places with low risk of crime and higher quality of life. These findings support previous research on procedural justice and police legitimacy, revealing that implementing procedural justice and increasing police legitimacy can have positive impacts on community life. This

finding is significant in that, to date, no one else has examined the extension of procedural justice and procedural justice to social disorder outcomes. Previous research stops when support is found for increased police legitimacy, assuming that this would improve conditions in communities. This analysis reveals the real-world utility in these concepts. 
The second purpose of this study was to examine the relationship between neighborhood atmosphere and perception of drug problems; fear of crime; overall quality of life; and risk of crime. Two of the three neighborhood types are statistically significant in relation to all four of the dependent variables. Interdependence is related to decreases in perceptions of drug issues, fear of crime, risk of crime, and increases in quality of life. Conversely, conflict is related to increases in perceptions of drug issues, fear of crime, risk of crime, and decreases in quality of life. Interestingly, dependence has similar effects to interdependence in a one instance. An increase in dependence results in a decrease (-18\%) in risk of crime. However, interdependence results in a greater decrease in risk of crime (-33\%). This suggests that individuals who report an atmosphere of dependence are better off than individuals who report an atmosphere of conflict, but not as well off as individuals who report an atmosphere of interdependence. Although the case of risk of crime illustrates dependence having a positive impact, the opposite was found in regard to perceptions of drug problems. Individuals who report an atmosphere of dependence have a 38\% higher chance of perceiving drug problems in their neighborhood. These results indicate that individuals who report having an atmosphere of interdependence in their neighborhood are by far the safest.

The third purpose of this study was to examine the influence of procedural justice, police legitimacy, and neighborhood atmosphere type in understanding community safety and quality of life in West Virginia. In all of these models, interdependence and conflict are statistically and practically significant. Interdependence is associated with decreases in perceptions of drug problems, perceptions of fear of crime, risk of crime, and increases in quality of life. Conflict is associated with increases in perception of drug problems, fear of crime, risk of crime, and decreases in quality of life. Dependence is statistically significant in relation to decreases in 
perceptions of drug problems. Lastly, procedural justice and police legitimacy are not statistically significant in any of the models except the one concerning overall quality of life (Table 4, Model 3) where increased police legitimacy is associated with a $19 \%$ increase in quality of life $(\mathrm{p}<.05)$, controlling for procedural justice and neighborhood atmosphere.

This model building approach reveals that examining procedural justice and police legitimacy without considering the neighborhood atmosphere excludes important aspects of neighborhood context. This analysis exposed that procedural justice and police legitimacy have positive impacts of communities, but a more complete picture includes measures of neighborhood atmosphere.

To date, Nolan and his colleagues examined neighborhood dynamics in three locations using traditional methods of data collection. However, in their analyses of Wilmington, Cleveland, and West Virginia the authors did not account for perceptions of police legitimacy and procedural justice. This paper extends the literature of procedural justice and police legitimacy as well as neighborhood dynamics in two important ways.

First, this paper examines the influence of procedural justice and police legitimacy in relation to four community variables focused on crime and disorder. The procedural justice literature is focused primarily on how procedural justice approaches and the resulting police legitimacy can impact individuals' decisions to obey the law or not. This paper examines this relationship, not in regard to future or past offending, but in terms of neighborhood outcomes: fear of crime in the neighborhood, risk of crime in the neighborhood, quality of life in the neighborhood, and drug problems in the neighborhood. This data suggests that procedural justice and police legitimacy are related to crime and disorder in communities, but to a lesser degree than neighborhood atmosphere type, as seen in Model 3's where significance is lost when 
controlling for neighborhood atmosphere. The data suggests that when communities work together and with law enforcement (interdependence) instead of against them (conflict) or rather than relying solely on them (dependence), communities have more positive outcomes. This also illustrates the importance of context when studying police-community relations. That is, when specific aspects of context are considered, the effects of procedural justice and police legitimacy disappear.

\section{Limitations}

As mentioned previously, this study has some notable limitations. First, the way the data was gathered resulted in a non-probability sample of individuals who had access to the Internet. Obviously, this sampling method excludes those who are not online or on Facebook. The second limitation involves Facebook friend networks. Because this survey was distributed online through existing social networks, only those who were friends of our friends were able to see the survey invitation. Another issue that relates to our friend networks is the fact that Dr. Nolan and myself are not originally from West Virginia. Having long-term residents share the post was instrumental in the distribution of the survey because their peer networks contained more West Virginian's than Dr. Nolan or myself.

The aforementioned limitations point to one major limitation, generalizability. The findings here are skewed on the basis of the non-probability sample excluding a large portion of West Virginia adults. This data does not accurately represent West Virginia residents in terms of gender, income, education, and employment status. These are key in understanding neighborhood dynamics and perceptions of police. Additionally, using community outreach organizations such as West Virginia University Extension Services might yield a representative sample. Extension has outreach coordinators in every county with the main task of creating 
better communities. These Extension agents could possibly distribute the survey to different networks of individuals that Dr. Nolan and myself were unable to reach.

\section{Practical Implications}

Nolan et al. (2018) highlights how useful neighborhood dynamics can be, specifically in reference to the police. Nolan et al. (2018) assert,

Exposing latent neighborhood dynamics is like dusting for latent fingerprints. If officers can see the dynamics of the neighborhood, they will better understand community apathy, hostility, alienation, or stop snitching campaigns. They will see these shared attitudes and behaviors are rooted in the failure of the police and community to meet each other's shared expectations" (p. 20-21).

When police understand community expectations, they can better meet those expectations resulting in less conflict and frustration. The argument posed here is that police have expectations of the public, and the public has expectations of the police, when these expectations are not met (on either end) frustration and conflict can emerge. These frustrations are a result of the game of policing.

Bourdieu (2013) describes the social world in the framework of a sporting game. Nolan et al. (2018) argues that currently the game of policing is based upon law enforcement outputs (arrests, citations, tickets, etc.). Neighborhood dynamics are not only measures of efficacy beliefs, they can also be used to illustrate a new way of policing, one which alters the goals of officers, moving from arrests and citations towards better understanding community expectations. For that to happen, the police need to change the way they play the game - the structure and function of policing needs to change. 
Nolan et al. (2018) offer an innovative framework that combines neighborhood dynamics with crime and disorder. Figure 1 shows this relationship. The vertical line indicates where the community sits (at one point in time) in reference to neighborhood atmosphere (interdependent, conflict, or dependence). In this sense, Nolan et al. (2018) refer to interdependence, conflict, or dependence, all likely existing in a community, but to what degree? For example, a community with more interdependence will sit higher on the vertical line while a community with more dependence sits lower on the vertical line. The horizontal axis represents the level of crime and disorder in the neighborhood with more crime being located on the left side of the axis and less crime being located on the right. With data on neighborhood dynamics and crime statistics researchers can situate a community at a point in time. Nolan et al. (2018) refer to these locations as "neighborhood types" and these are represented in Figure 1 as quadrants: strong, vulnerable, responsive, and anomic. Nolan et al. (2018) describes a "strong neighborhood" as "one where crime rates are low, and residents trust each other and the police to intervene as needed to keep it that way" (p. 22). Nolan et al. (2018) notes that the new desired outcome of police should be to move neighborhoods along this continuum to reach the status of a "strong neighborhood".

According to Nolan et al. (2018), vulnerable neighborhoods are places with low crime, but also places with low levels of collective efficacy. These neighborhoods rely almost entirely on the police to keep the community safe, and when those expectations are not met conflict and frustration can easily ensue.

Similar to vulnerable neighborhoods, anomic neighborhoods are places that rely heavily on police for safety. However, these are places that exhibit high crime rates, creating a burden on the police who are constantly being called out. It is in these types of neighborhoods that the police become frustrated with the community because they cannot deal with the high volume of 
calls to that neighborhood. The last neighborhood type offered by Nolan et al. (2018) is a responsive neighborhood. This neighborhood relies heavily on the community to deal with its high crime rate. Police may be involved in providing safety in this community, but the crime rate still persists. Because this "neighborhood type" spectrum relies on crime data, the only thing police would need to add would be measures of community dynamics to their current reporting protocols.

\section{Conclusion}

This paper offers a number of insights into reimagining policing using neighborhood data in conjunction with data on crime and disorder. This analysis shows that procedural justice and police legitimacy could have meaningful impacts on crime and disorder in neighborhoods. However, neighborhood dynamics are shown to be more impactful than procedural justice and police legitimacy in improving life in communities. These findings extend the literature of both procedural justice and police legitimacy and neighborhood dynamics. Additionally, this paper shows how these concepts can be used to better understand issues at a community level. Lastly, using Facebook as a method of obtaining respondents adds to the literature on using social media as a sampling tool.

This study resulted in a number of new directions that I would like to take in the future. First, I would like to explore further the mediating effect of neighborhood dynamics in the relationship between procedural justice and police legitimacy. For example, is procedural justice more influential in interdependent neighborhoods or dependent ones in improving the legitimacy of the police? Secondly, I would like to examine the relationship between procedural justice, legitimacy, and neighborhood dynamics as interaction terms. Also, I would like to look at variations in the dependent variables as continuous and interval variables rather than 
dichotomizing them. This would add more to the story by examining possible variations in perceptions of community in light of polyvictimization. Lastly, the previous two points would be made possible by obtaining a better sample of West Virginias. As mentioned in the limitations section, this data has some problems. Obtaining a more representative sample of West Virginians would make these research objectives possible.

I want to conclude with a few key takeaways from this study. With this study I have extended, established, and explored. I have extended research on procedural justice and police legitimacy in two major ways. To my knowledge, no one has extended the assumptions of police legitimacy to look at social disorder and safety at the local level. Additionally, no one has examined these perceptions while controlling for neighborhood dynamics. Secondly, I have established more support for the concept of neighborhood dynamics. Neighborhood dynamics is a relatively new and understudied concept, this work has really only been done by Dr. Nolan and his colleagues. Although the data has some limitations, we have found support for the concept, similar to what Nolan and colleagues found using phone survey data in West Virginia and doorto-door surveys in Wilmington and Cleveland. What this study adds to the previous literature on the topic is that my final models include procedural justice and police legitimacy measures to see which has a stronger impact on the dependent variables. Lastly, I have explored a relatively new methodology. As previously mentioned, this study grew out of a need to better gather quality of life data in West Virginia. I definitely obtained a larger sample in a much shorter time frame, but the sample was less representative of the state than I would have liked. What we did learn is that this method would be better suited to target hard to reach populations. 


\section{References}

About. (2018). Retrieved from https://blacklivesmatter.com/about/.

Bandura, A. (2001). "Social cognitive theory: An agentic perspective". Annual Review of Psychology 52: 1-26.

Bhutta, C. B. (2012). "Not by the Book: Facebook as a Sampling Frame." Sociological Research Methods \& Research, 41(1): 57-88.

Bourieu, P. 2013 [1977]. Outline of a theory of practice. Cambridge, MA: Cambridge University Press.

Donnermeyer, J., \& DeKeseredy, W.S. (2014). Rural criminology: New directions in critical criminology.” New York, NY: Routledge.

D’Souza, A., Weitzer, R., \& Brunson, R.K. (2018). "Federal investigations of police misconduct: A multi-city comparison." Crime, Law, and Social Change: 1-22.

Hinds, L, \& Murphy, K. (2007). "Public satisfaction with police: Using procedural justice to improve police legitimacy.” The Australian and New Zealand Journal of Criminology 40(1): 27-42.

Mapping police violence. (2018). Retrieved from https://mappingpoliceviolence.org/.

Nolan, J. J., Hinkle, J. C., \& DeKeseredy, W.S. (2018). Changing the game of policing: A Neighbourhood dynamics approach to police reform. Unpublished manuscript.

Nolan, J. J., Conti, N., \& McDevitt, J. (2004). “Situational policing: Neighbourhood development and crime control." Policing \& Society 14(2): 99-117.

President's task force on $21^{\text {st }}$ century policing. (2015). Final Report of the President's Task Force on $21^{\text {st }}$ Century Policing. Washington. DC: Office of Community Oriented Policing Services. 
Sampson, R. J. (1985). "Neighborhood and crime: The structural determinants of personal victimization." Journal of Research in Crime and Delinquency, 22(1): 7-40.

Sampson, R.J., \& Raudenbush, S. W. (1999). Systematic social observation of public spaces: A new look at disorder in urban neighborhoods." American Journal of Sociology, 105 (3): 603-651.

Sampson, R. J., Raudenbush, S. W., \& Earls, F. (1997). "Neighborhoods and violent crime: A multilevel study of collective efficacy." Science, 227: 918-934.

Sunshine, J., \& Tyler, T. R.. (2003). "Moral solidarity, identification with the community, and the importance of procedural justice: The police as prototypical representatives of a group's moral values." Social Psychology Quarterly, 66(2[Special Issue] Social Identity: Sociological and Social Psychological Perspectives): 153-165.

Tate, J., Jenkins, J., Rich, S., Muyskens, J., Elliott, K., Mellnik, T., \& Williams, A. (2018, July 7). How the Washington Post is examining police shootings in the United States. The Washington Post. Retrieved from https://www.washingtonpost.com/national/how-thewashington-post-is-examining-police-shootings-in-the-unitedstates/2016/07/07/d9c52238-43ad-11e6-8856-

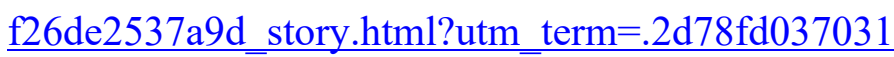

Thibaut, J. \& Walker, L. (1975). Procedural justice: A psychological analysis. Hillsdale, NJ: Lawrence Erlbaum Associates.

Tyler, T. R., \& Huo, Y. (2002). Trust in the law: Encouraging public cooperation with the police and courts. New York, NY: Russell Sage.

Tyler, T. R. (1998). "What is procedural justice?: Criteria used by citizens to assess the fairness of legal procedures." Law \& Society Review, 22(1): 103-136. 
Tyler, T. R. (2004). "Enhancing police legitimacy." The Annals of the American Academy, 593(1): 84-99.

Tyler, T. R. (2006). Why people obey the law. Princeton, NJ: Princeton University Press.

Williams, H. E., Bowman, S. W., \& Jung, J. T. (2016). "The limitations of government databases for analyzing fatal officer-involved shootings in the United States.” Criminal Justice Policy Review: 1-22.

Worden, R. E, \& McLean, S. J. (2017). Mirage of police reform: Procedural justice and police legitimacy. University of California Press: Oakland, CA. 
Figure 1: Neighborhood Developmental Stages

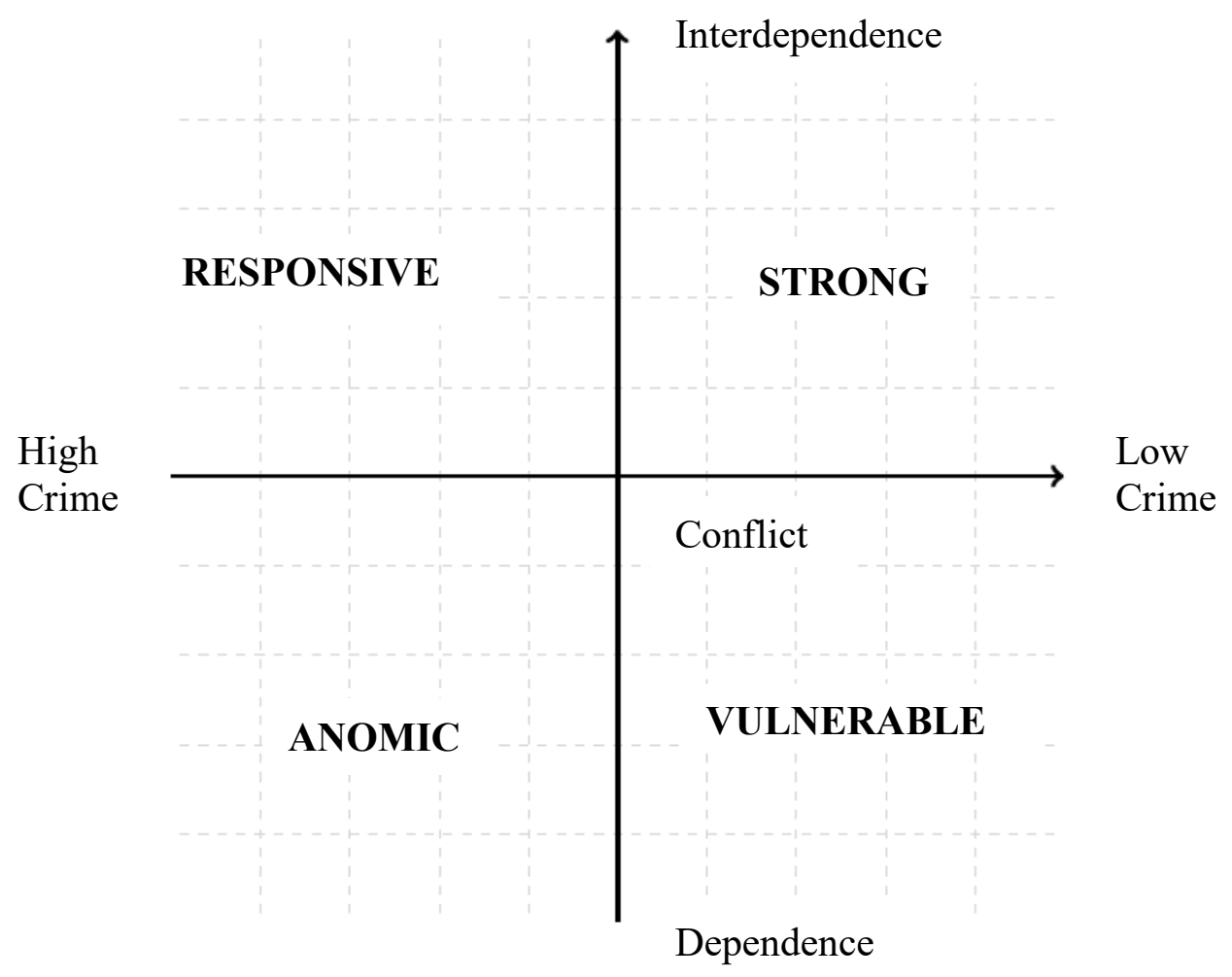


Table 1 - Phone Survey Vs. Online Survey Proportion Comparisons

\begin{tabular}{|l|c|c|c|}
\hline & \multicolumn{2}{|c|}{$\begin{array}{l}\text { West Virginia Quality of Life Phone Survey } \\
(\mathrm{n}=383)\end{array}$} & $\begin{array}{c}\text { West Virginia Quality } \\
\text { of Community Life } \\
\text { Online Survey } \\
(\mathrm{n}=1,431)\end{array}$ \\
\hline & Proportion & $95 \%$ Confidence Intervals & Proportion \\
\hline Robbery & 0.009 & $-0.0008-0.019$ & 0.003 \\
\hline Assault & 0.022 & $0.007-0.037$ & 0.034 \\
\hline & \multicolumn{3}{|c|}{0.773} \\
\hline $\begin{array}{l}\text { Watch out for } \\
\text { each other's } \\
\text { property }\end{array}$ & 0.8479 & $0.8021-0.8847$ & 0.263 \\
\hline $\begin{array}{l}\text { Are frustrated } \\
\text { with the police }\end{array}$ & 0.1787 & $0.1386-0.2273$ & 0.592 \\
\hline $\begin{array}{l}\text { Call the police } \\
\text { for most } \\
\text { community } \\
\text { problems }\end{array}$ & 0.6224 & $0.5644-0.6770$ & 0.277 \\
\hline $\begin{array}{l}\text { Think the } \\
\text { local police } \\
\text { are ineffective }\end{array}$ & 0.2644 & $0.2170-0.3180$ & \\
\hline
\end{tabular}

Table 2 - DV: Drug Problem

\begin{tabular}{|l|c|c|c|}
\hline & Model 1 & Model 2** & Model 3** \\
\hline & Odds Ratio & Odds Ratio & Odds Ratio \\
\hline Legitimacy & 0.95 & & 0.95 \\
& $(0.04)$ & & $(0.05)$ \\
\hline Procedural Justice & 0.93 & & 1.01 \\
& $(0.04)$ & & $(0.05)$ \\
\hline Interdependence & & $0.69^{* *}$ & $0.71^{* *}$ \\
& & $(0.05)$ & $(0.06)$ \\
\hline Conflict & & $1.92^{* *}$ & $1.89^{* *}$ \\
& & $(0.15)$ & $(0.16)$ \\
\hline Dependence & & $1.38^{* *}$ & $1.42^{* *}$ \\
& & $(0.11)$ & $(0.12)$ \\
\hline Constant & & $2.94^{* *}$ & 3.52 \\
& $\left(2.13^{* *}\right.$ & $(0.23)$ & $(1.88)$ \\
\hline Psuedo $\mathrm{R}^{2}$ & 0.005 & 0.09 & 0.09 \\
\hline
\end{tabular}




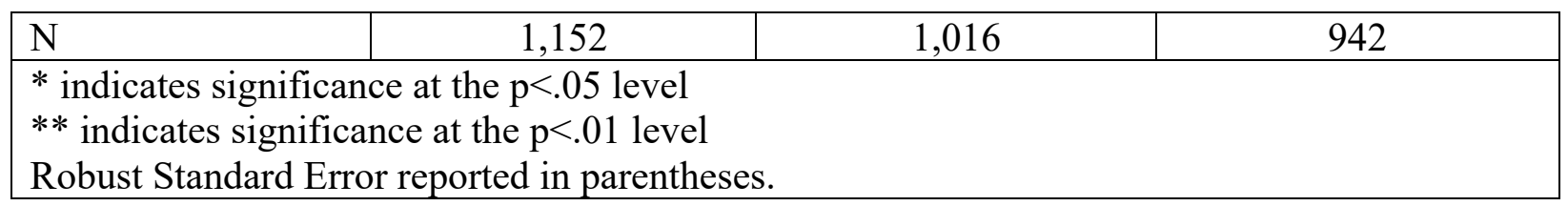

Table 3 - DV: Fear of Crime

\begin{tabular}{|l|c|c|c|}
\hline & Model 1* & Model 2** & Model 3** \\
\hline & Odds Ratio & Odds Ratio & Odds Ratio \\
\hline Legitimacy & 0.96 & & 0.99 \\
& $(0.04)$ & & $(0.04)$ \\
\hline Procedural Justice & $0.88^{* *}$ & & 0.98 \\
& $(0.03)$ & $0.56^{* *}$ & $0.05)$ \\
\hline Interdependence & & $(0.04)$ & $(0.04)$ \\
& & $1.76^{* *}$ & $1.76^{* *}$ \\
\hline Conflict & & $(0.12)$ & $(0.14)$ \\
& & 0.98 & 1.02 \\
& & $(0.07)$ & $(0.08)$ \\
\hline Dependence & $4.57^{* *}$ & 1.10 & 1.44 \\
& $(1.53)$ & $(0.07)$ & 0.10 \\
\hline Constant & 0.01 & 0.09 & 941 \\
\hline Psuedo R & 1,151 & 1,014 & \\
\hline N & & & \\
\hline * indicates significance at the $\mathrm{p}<.05$ level & & \\
** indicates significance at the $\mathrm{p}<.01$ level & \\
Robust Standard Error reported in parentheses.
\end{tabular}

Table 4 - DV: Overall Quality of Life

\begin{tabular}{|l|c|c|c|}
\hline & Model 1** & Model 2** & Model 3** \\
\hline & Odds Ratio & Odds Ratio & Odds Ratio \\
\hline Legitimacy & $1.23^{* *}$ & & $1.19^{*}$ \\
& $(0.08)$ & & $(0.09)$ \\
\hline Procedural Justice & $1.34^{* *}$ & & 1.08 \\
& $(0.08)$ & & $(0.08)$ \\
\hline Interdependence & & $2.97^{* *}$ & $3.08^{* *}$ \\
& & $(0.36)$ & $(0.39)$ \\
\hline Conflict & & $0.44^{* *}$ & $0.47^{* *}$ \\
& & $(0.05)$ & $(0.06)$ \\
\hline Dependence & & 1.14 & 1.05 \\
& & $(0.13)$ & $0.14)$ \\
\hline Constant & $0.07^{* *}$ & $4.80^{* *}$ & 0.83 \\
& $(0.04)$ & $(0.56)$ & $0.64)$ \\
\hline Psuedo $\mathrm{R}^{2}$ & 0.09 & 0.24 & 0.28 \\
\hline $\mathrm{N}$ & 835 & 731 & 692 \\
\hline
\end{tabular}


$*$ indicates significance at the $\mathrm{p}<.05$ level

$* *$ indicates significance at the $\mathrm{p}<.01$ level

Robust Standard Error reported in parentheses.

Table 5 - DV: Risk of Crime

\begin{tabular}{|c|c|c|c|}
\hline & Model 1** & Model 2** & Model 3** \\
\hline & Odds Ratio & Odds Ratio & Odds Ratio \\
\hline Legitimacy & $\begin{array}{l}0.88 * \\
(0.04)\end{array}$ & & $\begin{array}{c}0.93 \\
(0.05)\end{array}$ \\
\hline Procedural Justice & $\begin{array}{l}0.88^{*} \\
(0.04)\end{array}$ & & $\begin{array}{c}0.99 \\
(0.05)\end{array}$ \\
\hline Interdependence & & $\begin{array}{l}0.67 * * \\
(0.05)\end{array}$ & $\begin{array}{l}0.70^{* *} \\
(0.05) \\
\end{array}$ \\
\hline Conflict & & $\begin{array}{l}1.54 * * \\
(0.12)\end{array}$ & $\begin{array}{l}1.51 * * \\
(0.13)\end{array}$ \\
\hline Dependence & & $\begin{array}{c}0.82 * * \\
(0.06)\end{array}$ & $\begin{array}{c}0.87 \\
(0.07)\end{array}$ \\
\hline Constant & $\begin{array}{c}2.10 \\
(0.85) \\
\end{array}$ & $\begin{array}{l}0.29 * * \\
(0.02)\end{array}$ & $\begin{array}{c}0.46 \\
(0.24)\end{array}$ \\
\hline Psuedo $\mathrm{R}^{2}$ & 0.02 & 0.06 & 0.06 \\
\hline $\mathrm{N}$ & 1,155 & 1,018 & 945 \\
\hline \multicolumn{4}{|c|}{$\begin{array}{l}* \text { indicates significance at the } \mathrm{p}<.05 \text { level } \\
* * \text { indicates significance at the } \mathrm{p}<.01 \text { level } \\
\text { Robust Standard Error reported in parentheses. }\end{array}$} \\
\hline
\end{tabular}




\section{Appendix: Quality of Community Life in West Virginia}

\section{Start of Block: INTRO AND SCREENING QUESTIONS}

Researchers at West Virginia University (WVU) want to know more about community life in West Virginia. Specifically, they are interested in knowing more about what makes a community safe. Here is a quick way for you to weigh in and tell them what it is like where you live. This study, entitled "The Quality of Community Life in West Virginia," has been reviewed and approved by the WVU IRB (Protocol \#1707651914) and it is on file. This study is being conducted by Dr. James Nolan (the principal investigator) from West Virginia University and Robert Nicewarner (Sociology Ph.D. student) who will apply the findings to his doctoral research. The purpose of this research study is to identify social factors that may influence the life experiences of West Virginia residents. We anticipate that the data will be useful to community members, government officials and public policy makers as they work together to improve conditions for all West Virginians.

This survey will take approximately 5 minutes of your time. Your participation in this research is voluntary and your responses will remain completely anonymous. You can refuse to participate and if you feel uncomfortable answering any question you may decline to respond and continue on to the next question or quit at any time. There are no foreseeable risks and no costs, payments, or benefits to participating in this study. However, I think you may find this survey interesting and we anticipate that the findings will be enlightening.

Thank you for your time and help with this project!

Sincerely,

Dr. James J. Nolan - Principal Investigator

Robert L. Nicewarner - Sociology PH.D student

Department of Sociology and Anthropology304.293.8582309 Knapp Hall, Morgantown, WV

26505jjnolan@mail.wvu.edu 
I first need to know if you are currently 18 or older?

18 or older

NOT 18 or older

Are you currently a West Virginia resident?

Yes, WV Resident

No, NOT a WV Resident

End of Block: CONSENT

Start of Block: FEAR OF CRIMIE

When we ask questions about your community we are referring to the geographic area where you live. Your neighbors are the people who live around you. The size of this area may vary 
depending on the type of place you live, such as in a town or in a rural area.

In this first set of questions, we would like to know how safe you feel in your community. Could you tell us how worried you are about the following things happening to you?

\begin{tabular}{|c|c|c|c|c|c|}
\hline & $\begin{array}{l}\text { Not at All } \\
\text { Worried }\end{array}$ & $\begin{array}{l}\text { Not Very } \\
\text { Worried }\end{array}$ & Fairly Worried & Very Worried & $\begin{array}{c}\text { Don't } \\
\text { Know/Not } \\
\text { Applicable }\end{array}$ \\
\hline $\begin{array}{l}\text { Having your } \\
\text { home broken } \\
\text { into and } \\
\text { something } \\
\text { stolen }\end{array}$ & & & & & O \\
\hline $\begin{array}{l}\text { Vandalism to } \\
\text { your home or } \\
\text { car }\end{array}$ & & & & & C \\
\hline $\begin{array}{c}\text { Being } \\
\text { mugged/robbed }\end{array}$ & & & & & \\
\hline $\begin{array}{c}\text { Being } \\
\text { physically } \\
\text { attacked } \\
\text { because of } \\
\text { your skin } \\
\text { color, ethnic } \\
\text { origin, or } \\
\text { religion }\end{array}$ & ( & & & & \\
\hline $\begin{array}{c}\text { Being sexually } \\
\text { assaulted by } \\
\text { strangers }\end{array}$ & & & & & \\
\hline $\begin{array}{c}\text { Being } \\
\text { physically } \\
\text { attacked by } \\
\text { strangers }\end{array}$ & & & & & \\
\hline $\begin{array}{c}\text { Being } \\
\text { physically } \\
\text { attacked by } \\
\text { someone you } \\
\text { know }\end{array}$ & & & & & \\
\hline $\begin{array}{c}\text { Being sexually } \\
\text { assaulted by } \\
\text { someone you } \\
\text { know }\end{array}$ & & & & & \\
\hline
\end{tabular}


What is your current age?

What sex do you most identify with?

Male

Female

Other

Do you think of yourself as:

Straight or Heterosexual
Gay
Lesbian
Bisexual
Transgender
Other


Are you now:

Married

Widowed

Divorced

Separated

Never married

Living with a romantic partner, but not married

What is the highest level of education you have completed?

No High School Degree

High School or GED

Vocational or Trade School

Some College or two-year Associate Degree

Four-year College Degree

Graduate Degree 
During the past 12 months, were you mainly:

Working Full-time

Working Part-time

Not working for a wage

Retired

Going to School

The median household income in West Virginia is about $\$ 42,000$ per year. How does your household compare?

Lower

About the same

Higher

Are you of Hispanic or Latino/a origin or background?

Yes

No 
What is your race?

White or Caucasian

Black or African American

Asian

American Indian or Alaskan Native

Native Hawaiian or other Pacific Islander

Middle Eastern (e.g. Saudi Arabia, Israel)

Other 
What county in West Virginia do you currently live in?

Barbour

Berkeley

Boone

Braxton

Brooke

Cabell

Calhoun

Clay

Doddridge

Fayette

Gilmer

Grant

Greenbrier

Hampshire

Hancock

Hardy

Harrison

Jackson

Jefferson

Kanawha 
Lewis

Lincoln

Logan

Marion

Marshall

Mason

McDowell

Mercer

Mineral

Mingo

Monongalia

Monroe

Morgan

Nicholas

Ohio

Pendleton

Pleasants

Pocahontas

Preston

Putnam

Raleigh 
Randolph

Ritchie

Roane

Summers

Taylor

Tucker

Tyler

Upshur

Wayne

Webster

Wetzel

Wirt

Wood

Wyoming

Overall, how would you rate your health in general?

Excellent

Very Good

Good

Fair

Poor 
Start of Block: CRIMIES

Did anyone ever break into your home, car, or garage?

$$
\text { Yes }
$$

No

(If respondent answered "Yes" to above)

Did it occur in the past 12 months?

Yes

No

\section{Page Break}

Was anything of yours ever stolen that was kept outside your home, such as a bicycle, toy, or lawn furniture?

Yes

No

(If respondent answered "Yes" to above)

Did it occur in the past 12 months?

Yes

No 
Was your car, truck, or motorcycle ever stolen?
Yes
No

(If respondent answered "Yes" to above)

Did it occur in the past 12 months?

Yes

No

\section{Page Break}

Did anyone ever mug or rob you via a stick up or by threatening to hurt you?
Yes
No

(If respondent answered "Yes" above)

Did it occur in the past 12 months?

Yes

No 
Did anyone ever hit, kick, slap, shove, or punch you?
Yes
No

(If respondent answered "Yes" above)

Did it occur in the past 12 months?

Yes

No

\section{Page Break}

Did anyone ever knife you, shoot at you, or attack you with a weapon?
Yes
No

(If respondent answered "Yes" above)

Did it occur in the past 12 months?
Yes
No 
Have you ever been verbally or physically assaulted because of your race, religion, sexual orientation, ethnicity, sex, political affiliation, disability, or other group characteristic?

Yes

No

(If respondent answered "Yes" above)

Did it occur in the past 12 months?

Yes

No 
Was it because of your real or perceived (can choose more than one):

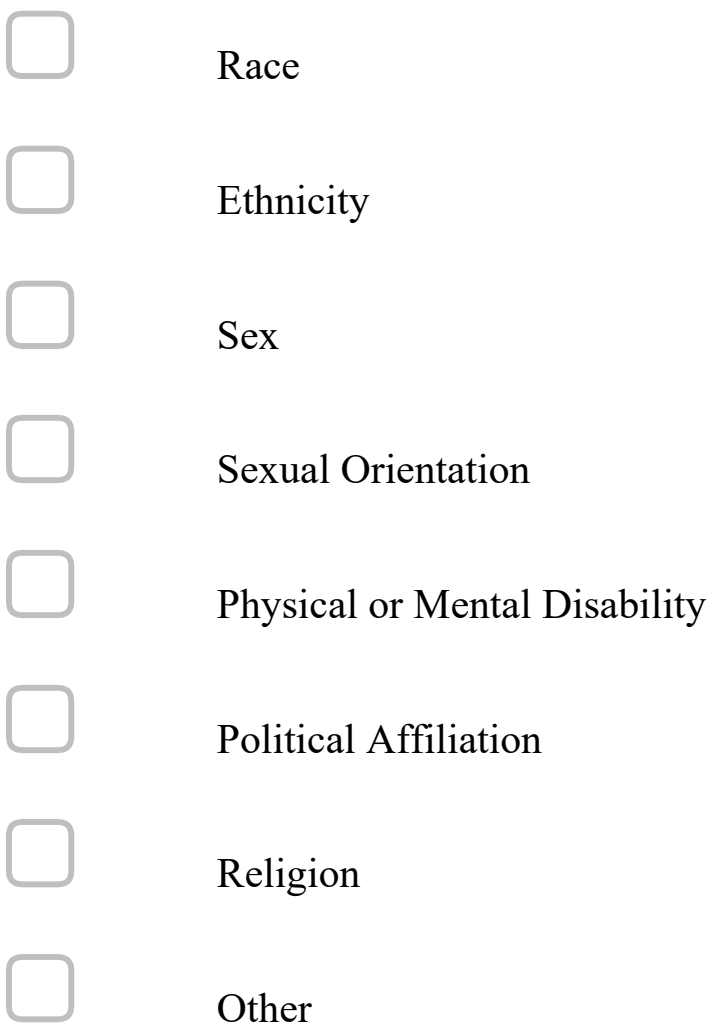

Page Break

Have you ever witnessed a crime?

Yes

No

(If respondent answered "Yes" above)

Did it occur in the past 12 months?

Yes

No 
What did you do?

Call the police or other legal authorities

Tried to stop it myself or with others

Did not intervene

Other

(If respondent answered "Did not intervene" above)

You are among the vast majority of people who have witnessed a crime and for a variety of reasons did not call the police or intervene directly to stop it. Can you briefly share with us the circumstances of the crime you witnessed and the reasons you chose not to call the police or intervene directly? 
People often feel most protective of the area around their own homes and, therefore, are most likely to intervene to prevent crimes in this area. How large is this area for you?

Less than 5 minute walk from your home.

A 5 to 15 minute walk from your home.

Greater than a 15 minute walk from your home.

Which of the following best describes the place you live?

City or town

Outskirts of city or town

Rural

Other

\section{End of Block: HATE CRIME HARASSMIENT}

\section{Start of Block: DRUGS}

Now I would like to ask you about drug use and drug dealing in your community. Is drug use or dealing not a problem, a small problem, or a big problem in your community?

Big Problem

Small Problem

Not a problem

Please elaborate if you would like. 
Now I would like to ask you questions about resident relations in your community. Please indicate your level of agreement for the following statements.

Generally speaking, the residents in my community...

\begin{tabular}{|c|c|c|c|c|c|c|}
\hline & $\begin{array}{l}\text { Strongly } \\
\text { Disagree }\end{array}$ & Disagree & Neutral & Agree & $\begin{array}{c}\text { Strongly } \\
\text { Agree }\end{array}$ & Don't know \\
\hline $\begin{array}{l}\text { know how } \\
\text { to work } \\
\text { together to } \\
\text { prevent } \\
\text { crime }\end{array}$ & & & & & & \\
\hline $\begin{array}{l}\text { don't get } \\
\text { along with } \\
\text { one another }\end{array}$ & & & & & & \\
\hline $\begin{array}{l}\text { know how } \\
\text { to deal with } \\
\text { minor } \\
\text { community } \\
\text { problems }\end{array}$ & & & & & & \\
\hline $\begin{array}{l}\text { are willing } \\
\text { to help one } \\
\text { another }\end{array}$ & & & & & & \\
\hline $\begin{array}{l}\text { watch out } \\
\text { for each } \\
\text { other's } \\
\text { property }\end{array}$ & & & & & & \\
\hline $\begin{array}{l}\text { tell each } \\
\text { other what } \\
\text { is going on }\end{array}$ & & & & & & \\
\hline $\begin{array}{l}\text { do not work } \\
\text { well } \\
\text { together on } \\
\text { community } \\
\text { problems }\end{array}$ & & ( & & & & \\
\hline $\begin{array}{l}\text { trust each } \\
\text { other }\end{array}$ & 0 & & ) & & & \\
\hline $\begin{array}{l}\text { rely heavily } \\
\text { on each } \\
\text { other }\end{array}$ & $\Omega$ & $\cap$ & & & & \\
\hline
\end{tabular}


Now I want to ask you about your perceptions of the police. Please indicate your level of agreement with the following statements. Would you say...

\begin{tabular}{c|c|c|} 
Strongly Disagree Neutral Agree & $\begin{array}{c}\text { Strongly } \\
\text { Agree }\end{array}$ Don't know \\
\hline $\begin{array}{c}\text { Disagree } \\
\text { concerned } \\
\text { about }\end{array}$ \\
respecting a \\
citizen's \\
individual \\
rights. \\
the police \\
treat people as \\
if they can be \\
trusted to do \\
the right \\
thing. \\
the police \\
treat people as \\
if they only \\
do the right \\
thing when \\
forced to. \\
the police in \\
my
\end{tabular}




\section{Start of Block: COLLECTIVE EFFICACY}

How would think your neighbors would most likely respond to the following situations?

If a group of children in the community were skipping school and hanging out in a public place, how would the residents of your community likely respond?

Intervene directly or call on other community members to intervene

Call on police or other legal authorities

Would not intervene

Other

If one of your community members was being beaten by a current or ex-spouse, how would residents in your community most likely respond?

Intervene directly or call on other community members to intervene

Call on police or other legal authorities

Would not intervene

Other 
If there was a fight in the street in front of your house, how would people in your community most likely respond?

Intervene directly or call on other community members to intervene

Call on police or other legal authorities

Would not intervene

Other

If there was stranger walking through your community in the evening looking into cars and trying to open doors, how would your neighbors most likely respond?

Intervene directly or call on other community members to intervene

Call on police or other legal authorities

Would not intervene

Other 
How confident are you that your neighbors know how to successfully intervene in the following situations so that things improve?

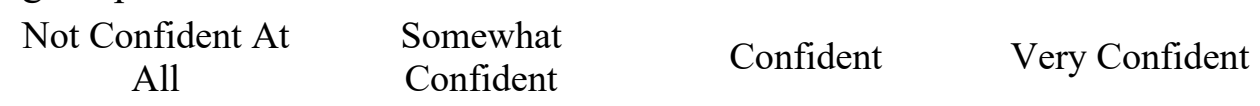

\section{Help a person \\ who is struggling with drug or alcohol addiction.}

Help neighbors settle disputes without violence.

Help a neighbor having serious domestic problems.

Help a neighbor who is threatening suicide.

If a person returned to the neighborhood from prison, how likely is it that they would be supported by your neighbors?

Very unlikely

Unlikely

Neither likely or unlikely

Likely

Very likely 
How would you rate the overall quality of community life in West Virginia?

Very bad

$\mathrm{Bad}$

Neither bad nor good

Good

Very good

Start of Block: COMMENTS

We really appreciate the time you have taken to complete this survey. And we'd like to assure you that everything you have told me will remain strictly anonymous.

We realize that the topics covered in this survey are sensitive and that many people are reluctant to talk about some of their community experiences. But I'm also a bit worried that I haven't asked the right questions.

So now that you have had a chance to think about the topics covered in this survey, would you like to provide me with any additional information about the quality of life in your community?

Like the rest of your responses to this survey, any information you provide here is anonymous and will be grouped and reported with other respondents' comments.

\section{End of Block: COMMENTS}

Start of Block: END

That is all the questions I have for you today. If you have questions for us about the research study or your participation in it, you may call the Principal Investigator at 304-293-8582. In the event you found any of the questions stressful or discomforting, the National Organization for Victim Assistance may be reached at 1-800-TRY-NOVA (1-800-879-6682). The Substance Abuse \& Mental Health Services Administration may be reached at 1-877-SAMHSA- 7 (1-877726-4727). The National Domestic Violence Hotline is available to you 24 hours a day, 7 days a 
week at 1-800-799-SAFE. The National Sexual Assault Hotline is also available at 1-800-656HOPE. Thank you for participating, your opinions do count. 